\title{
Genotyping of Helicobacter pylori Virulence Genes cagA and vacA: Regional and National Study
}

\author{
Rania M. Kishk (D), ${ }^{1}$ Nashaat M. Soliman, ${ }^{2}$ Maha M. Anani, ${ }^{3}$ Nader Nemr, ${ }^{2}$ Ayman Salem, ${ }^{4}$ \\ Fawzy Attia, ${ }^{4}$ Amal Nooredeen Ahmed Allithy, ${ }^{5}$ and Marwa Fouad ${ }^{1}$ \\ ${ }^{1}$ Microbiology and Immunology Department, Faculty of Medicine, Suez Canal University, Ismailia, Egypt \\ ${ }^{2}$ Endemic and Infectious Diseases Department, Faculty of Medicine, Suez Canal University, Ismailia, Egypt \\ ${ }^{3}$ Clinical Pathology Department, Faculty of Medicine, Suez Canal University, Ismailia, Egypt \\ ${ }^{4}$ Internal Medicine Department, Faculty of Medicine, Suez Canal University, Ismailia, Egypt \\ ${ }^{5}$ Pathology Department, Faculty of Medicine, Sohag University, Sohag, Egypt \\ Correspondence should be addressed to Rania M. Kishk; raniakishk@med.suez.edu.eg
}

Received 11 February 2021; Revised 21 May 2021; Accepted 10 June 2021; Published 30 June 2021

Academic Editor: Rossella Grande

Copyright (c) 2021 Rania M. Kishk et al. This is an open access article distributed under the Creative Commons Attribution License, which permits unrestricted use, distribution, and reproduction in any medium, provided the original work is properly cited.

\begin{abstract}
Helicobacter pylori (H. pylori) plays a crucial role in the pathogenesis of gastritis, peptic ulcer, and gastric cancer. The presence of pathogenicity islands (PAI) genes contributes to the pathogenesis of many gastrointestinal disorders. Cytotoxin-associated gene A ( cagA) and vacuolating cytotoxin gene ( vacA) are the most known virulence genes in $H$. pylori. So, our aim was to study $H$. pylori virulence genes' role in gastric disorders pathogenesis. Our study included 150 adult patients who suffered dyspeptic symptoms and were referred to the GIT endoscopy unit. Gastric biopsies were attained for rapid urease test (RUT) and histopathological examination, and multiplex PCR technique for detection of virulence genes was performed. It was found that 100 specimens were (RUT) positive, of which sixty samples $(60 \%)$ were PCR positive for $H$. pylori ureC gene. The vacA and cagA genes were identified in $61.6 \%$ and $53 \%$ of $H$. pylori strains, respectively. Only 5 cases were $v a c A$-positive and cagA-negative. The most virulent vacA s1 allele existed in $56.6 \%$ of cases. Out of the $60 \mathrm{H}$. pylori strains, $66 \%$ had at least one virulence gene and $34 \%$ did not show any virulence gene. $H$. pylori infection showed significant increase with age. $H$. pylori are prevalent amid dyspeptic patients in our region. The main genotype combinations were $v a c A+/ c a g A+$ of $s 1 \mathrm{~m} 1$ genotype and they were frequently associated with peptic ulcer diseases, gastritis, and gastroesophageal reflux disease.
\end{abstract}

\section{Introduction}

H. pylori infection causes Peptic Ulcer Disease (PUD) and Gastric Carcinoma (GC) and affects almost half of the world's population [1]. H. pylori virulent strains and the host genetic condition were blamed for a wide variety of gastric disorders. $H$. pylori virulence genes encode the proteins which are responsible for damaging the gastric epithelium.

The H. pylori pathogenicity island (PAI) was initially known as cytotoxin-associated gene ( $\mathrm{cag})$, since it was assumed to be related to expression of the vacuolating toxin $(\operatorname{vac} A)$. However, it was afterwards demonstrated that both factors, vacA and the PAI, are separate of each other, even though cag-negative strains often do not express vacA [2].
The pathogenicity island (cagA-PAI) is found in the most virulent $H$. pylori strains. CagA-PAI is about $40 \mathrm{~kb}$ region, containing 31 genes that encode a type IV secretion system, related to cagA translocation and the host's inflammatory response [3]. CagA encodes a $120-145 \mathrm{kDa}$ immunodominant protein and is placed at the end of the cagA-PAI [4]. This protein is located on the plasma membrane and is phosphorylated at Glu-Pro-Ile-Tyr-Ala (EPIYA) motifs [5].

The numbers and types of EPIYA motifs at the C-terminal region determine the biological activity of cagA. After translocation, cagA disrupts the signal transduction of gastric epithelial cells producing cytokines which cause chronic gastritis and induce carcinogenesis designating cag $\mathrm{A}$ as the first bacterial oncoprotein [6]. 
Vacuolating cytotoxin A (vacA) can interrupt the endocytic trafficking, release organic anions and $\mathrm{HCO}_{3}$, enhance the immune tolerance, and promote chronic infection by inhibiting immune cells, stimulation of protein kinases, and autophagy modulation [7]. H. pylori strains carrying the vacA gene vary in their vacuolating ability, due to five $v a c A$ regions variations: s-region ( $s 1$ and $s 2$ ), i-region (i1, i2, i3), m-region ( $m 1$ and $m 2)$, d-region ( $d 1$ and $d 2)$, and c-region ( $c 1$ and $c 2)$ [8].

VacA gene $m$ region variants affect toxin binding to host cells [9]. vacA $s 1 m 1$ variants are the most virulent arrangement, $s 1 \mathrm{~m} 2$ strains toxin production is modest, and $s 2 m 2$ strains are rare or not found [10].

Although it is attained in childhood, the highest age groups at risk of $H$. pylori infection and its mode of transmission are unclear [11]. Identifying the age at which infection may cause gastric symptoms in Egyptian patients would help to appropriately apply preventive plans.

The application of multiplex PCR methods improved our information about $H$. pylori regulatory genes. In this work, we studied $H$. pylori virulence genes in infected patients suffering from dyspepsia after gastric biopsy and the association between those genes and endoscopic findings detected.

\section{Materials and Methods}

This cross-sectional descriptive study involved 150 adult dyspeptic patients who were referred to GIT endoscopy unit, aged between 18 and 75 years. Patients with previous gastric surgery were excluded from the study. Patients receiving antimicrobial agents, bismuth, proton pump inhibitors, or $\mathrm{H} 2$ receptor antagonists within the 4 weeks preceding endoscopic examination were also excluded. Informed consents were taken from all participants before starting our study. The ethics committee had reviewed and approved the study.

From each patient enrolled in our study, three gastric biopsies were obtained (two antrum biopsies and one fundus biopsy). One of them was used to screen $H$. pylori positive specimens by rapid urease test (RUT). Other biopsies were transported to the pathology lab for histopathological evaluation according to the revised Sydney classification for gastritis [12], using both H\&E staining and Giemsa stain, and according to the microbiology lab in brucella broth with $0.5 \%$ agar as a transport media for polymerase chain reaction (PCR) technique.

In patients with RUT positive, DNA from gastric biopsies was extracted, after being crushed and homogenized well, using QIAamp DNA Mini Kit (50) 51304 from QIAGEN, USA (catalogue number \#51304) following the manufacturer's instructions. First, the samples were incubated at $37^{\circ} \mathrm{C}$ for $12 \mathrm{~h}$ in $2 \mathrm{ml}$ brucella broth media and then centrifuged at $10.000 \times \mathrm{g}$ for $5 \mathrm{~min}$. PCR was performed to amplify the $u r e C(\mathrm{glmM})$ gene (nt 784-1077, $294 \mathrm{bp})$ using the following primers: forward primer: $5^{\prime}$-AAGCTTTTA GGGGTGTTAGGGGTTT- ${ }^{\prime}$ and reverse primer: $5^{\prime}$-AAGC TTACTTTCTAACACTAACGC- $3^{\prime}$. PCR conditions consisted of 30 amplification cycles $\left(1 \mathrm{~min}\right.$ at $93^{\circ} \mathrm{C}, 1 \mathrm{~min}$ at $55^{\circ} \mathrm{C}$, and $1 \mathrm{~min}$ at $72^{\circ} \mathrm{C}$ ) [13].

Multiplex PCR was used to identify vacA and cagA genes in samples positive for ureC $(\mathrm{g} \operatorname{lm} M)$ gene [14] using primers for vacA $s 1 / v a c A s 2$, vacA $m 1 / v a c A m 2$, and $\operatorname{cag} A$ (Table 1). Agarose gel (2\%) with ethidium bromide was used for separation of the PCR product, using a $100 \mathrm{bp}$ ladder as DNA molecular weight standard.

2.1. Statistical Analysis. Statistical analysis was done using IBM Statistical Package for the Social Sciences (SPSS) software, version 20.0, for Windows. Data was presented as mean \pm standard deviation or percentages. Chi-squared test was used for categorical variables. $P$ value was significant at $<0.05$.

\section{Results}

150 patients were enrolled from the endoscopy unit. Age ranged from 18 to 75 years $(57.2 \pm 16.34) ; 60 \%$ of them were females, and $65 \%$ of them were from rural area. No one received nonsteroidal anti-inflammatory drugs. Recurrent abdominal pain was the most common presentation followed by nausea, vomiting, dyspepsia, and heart burn (60\%, $39 \%, 24 \%$, and $20 \%$, respectively).

Antral gastritis was the most predominant endoscopic finding followed by Gastroesophageal Reflux Disease (GERD) and pangastritis $(36.6 \%, 34 \%$, and $26.6 \%$, respectively). Normal gastric mucosa was found in only 4 patients (2.6\%). Chronic superficial gastritis was the most common finding in histopathological examination, some of which showing mild chronic inflammation with no activity (Figure 1) and others showing moderate chronic inflammation (Figures 2 and 3), followed by atrophic gastritis (Figures 4 and 5), chronic active gastritis (Figure 6), and duodenitis $(70 \%, 20 \%, 10 \%$, and $6 \%$, respectively).

Out of the 150 studied patients, 100 patients (66.6\%) were RUT positive. All patients with antral gastritis and combined duodenal and gastric ulcers were RUT positive. Antral gastritis, diffuse erosive gastroduodenitis, duodenal ulcer, gastric ulcer, and combined duodenal and gastric ulcer had statistically significant association with RUT $(P<0.001$, $<0.001,0.03,0.017$, and 0.04, respectively).

PCR was performed for all RUT positive samples (100 samples), where 60 samples $(60 \%)$ were positive for $H$. pylori ureC $(\mathrm{g} \operatorname{lm} M)$ gene (Figure 7). Antral gastritis represented the most common endoscopic result in patients positive for H. pylori by PCR followed by duodenal ulcer and GERD (33.3\%, 28.3\%, and 25\%, respectively). Pan gastritis, diffuse erosive gastroduodenitis, duodenal ulcer, gastric ulcer, and combined duodenal and gastric ulcer showed statistically significant relation with PCR results $(P<0.001)$ (Table 2$)$.

$v a c A$ and $\operatorname{cag} A$ genotypes were identified by multiplex PCR (Figure 8). The vacA and $\operatorname{cag} A$ genes were identified in $37(61.6 \%)$ and $32(53 \%)$ of the $60 \mathrm{H}$. pylori strains, respectively. All strains with $\operatorname{cag} A$ gene were vacA gene positive. Only 5 cases were $v a c A$ positive and $\operatorname{cag} A$ negative. 
TABle 1: Primers used for the amplification of vacA alleles and cagA.

\begin{tabular}{lcccc}
\hline Region amplified & Primers & Primers sequence & Amplicon size & Ref \\
\hline \multirow{2}{*}{$v a c A s 1 / v a c A s 2$} & VAI-F & $5^{\prime}$-ATGGAAATACAACAAACACAC-3' & $259 / 286$ & Ito et al. [15] \\
& VAI-R & $5^{\prime}$-CTGCTTGAATGCGCCAAAC-3' & & Jones et al. [7] \\
\multirow{2}{*}{ cagA $m 1 / v a c A m 2$} & VAG-F & $5^{\prime}$-CAATCTGTCCAATCAAGCGAG-3' & $567 / 642$ & \\
& VAG-R & $5^{\prime}$-GCGTCAAAATAATCCAAGG-3' & & Graham and Yamaoka [16] \\
\hline
\end{tabular}

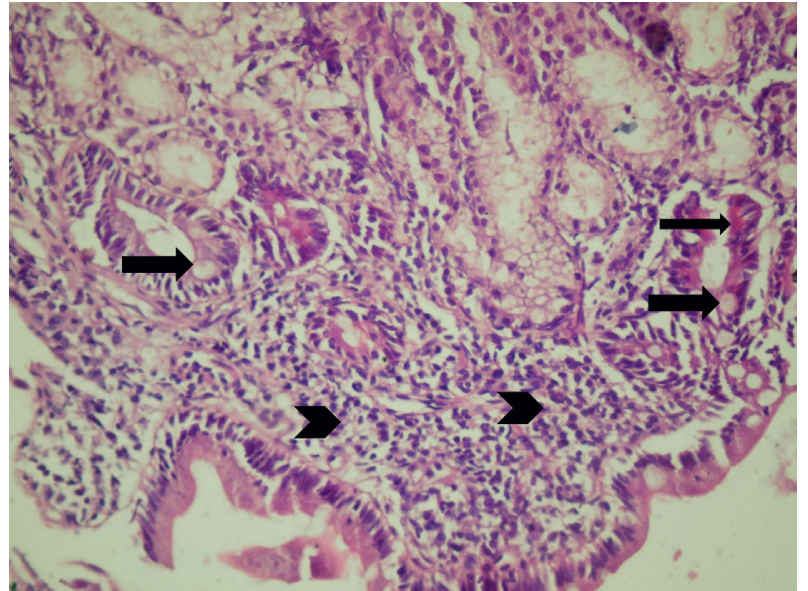

FIgURE 1: Photomicrograph showing antral chronic superficial gastritis with mixed inflammatory cell infiltrate (arrow heads), mainly lymphocytes and plasma cells; some glandular epithelial cells show intestinal metaplasia, with goblet cells (thick arrow) and Paneth cells (thin arrows), H\&E, $\times 200$.

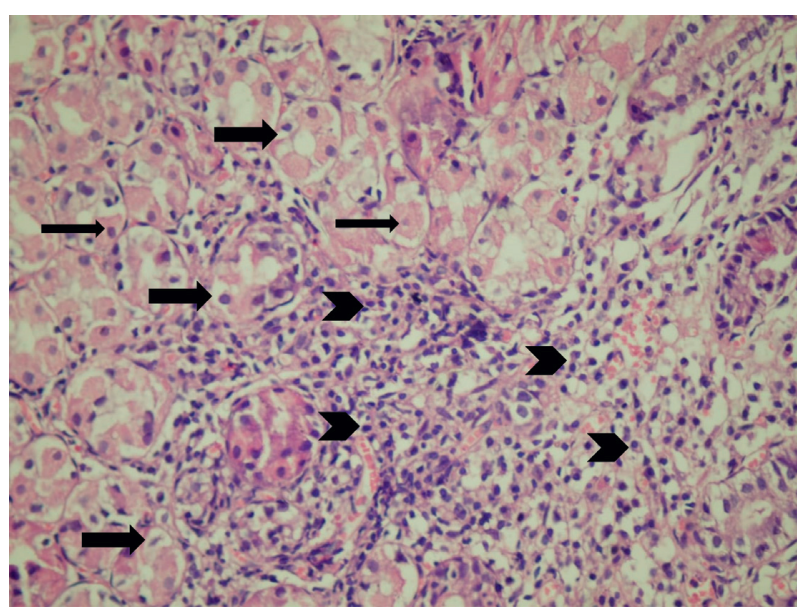

FIgURE 2: Photomicrograph showing chronic superficial gastritis with mixed inflammatory cell infiltrate (arrow heads), mainly lymphocytes and plasma cells; some glandular epithelial cell shows reactive changes, for example, subnuclear vacuolization (arrows) and parietal cell hyperplasia (thin arrow), $\mathrm{H} \& \mathrm{E}, \times 200$.

H. pylori patients with PUD, gastritis, and GERD (50\%, $41.6 \%$, and $25 \%$, respectively) had statistically significant association with $\operatorname{cagA}$ genotype $(P<0.001)$. The most virulent vacA s1 allele was represented in 34 cases (56.6\%). The middle region vacA $m 1$ was predominant in 27 cases (45\%),

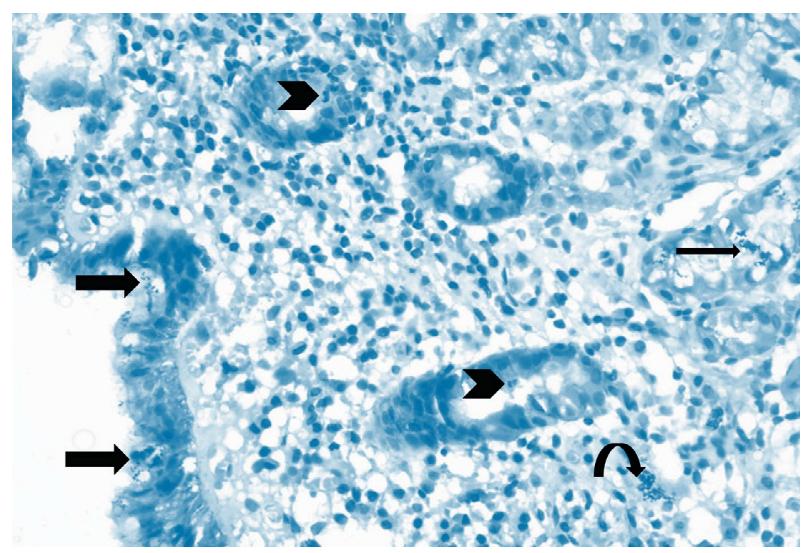

FIGURE 3: Photomicrograph showing chronic superficial active gastritis (arrow heads pointing to neutrophils attacking glandular epithelium), with mixed inflammatory cell infiltrate, mainly lymphocytes and plasma cells. Helicobacter pylori are present in the superficial mucous layer (thick arrow), within the glands, and in the lamina propria (curved arrow), Giemsa stain, $\times 200$.

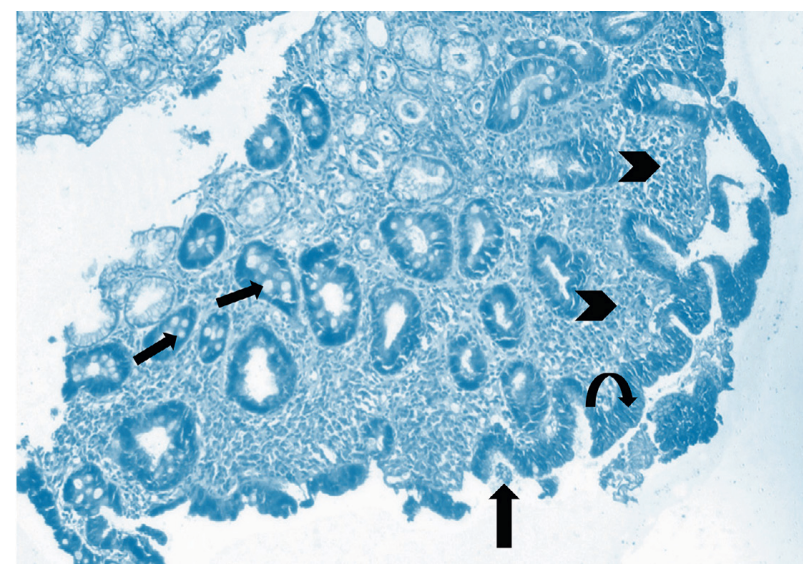

FIgURE 4: Photomicrograph showing atrophic gastritis with mixed inflammatory cell infiltrate (arrow heads). Helicobacter pylori are present in the superficial mucous layer (thick arrow) and intestinal metaplasia with goblet cells (thin arrow), with marked loss of mucosal glands and mucin depletion in the surface epithelium due to regenerative changes (curved arrow). Giemsa stain, $\times 100$.

while $m 2$ and $s 2$ genotypes were detected in $10(16.6 \%)$ and 3 (5\%) cases, respectively (Table 3 ).

The vacA $s 1 \mathrm{~m} 1 / \mathrm{cagA}+$ was found in 26 cases $(43.3 \%)$, while vacA s $1 \mathrm{~m} 2 / \mathrm{cag} A+$ were found in 5 strains only (8.3\%). We did not find vac $s 2 m 1$ genotype, either cagA positive or negative. The vac $s 2 m 2$ genotype was detected in 3 patients; 


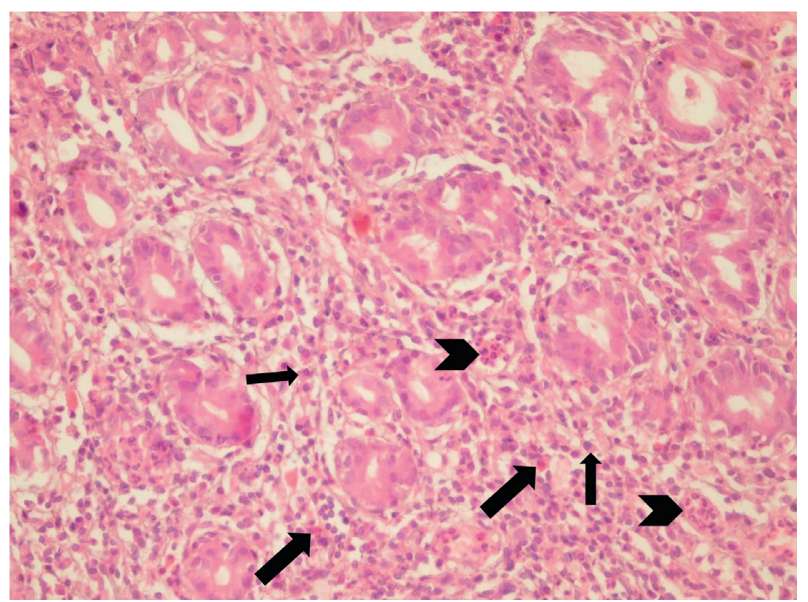

FIgURE 5: Photomicrograph showing chronic active gastritis with large number of neutrophils (arrow heads) and mixed inflammatory cell infiltrate, namely, plasma cells (thin arrow), lymphocytes (arrow heads), and eosinophils (thick arrow), with moderate atrophy, H\&E stain, $\times 200$.

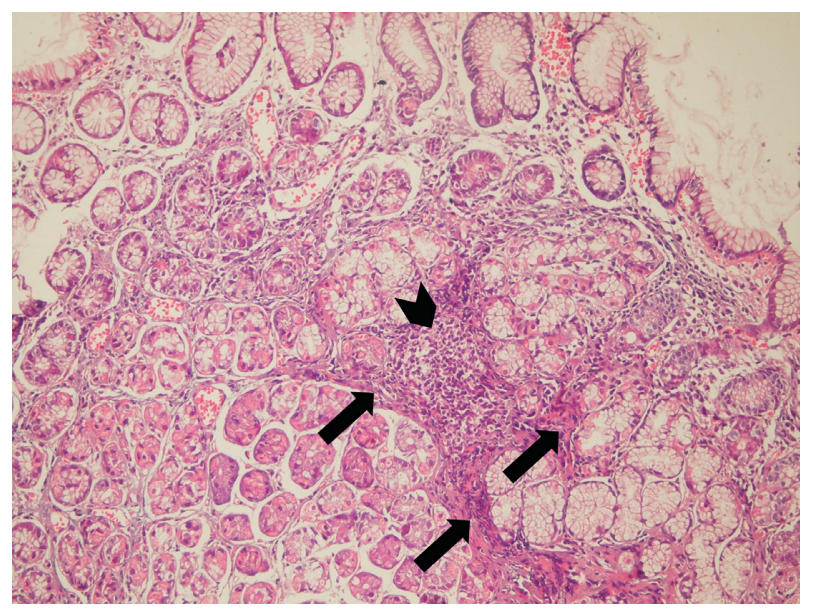

FIGURe 6: Photomicrograph showing chronic gastritis with mixed inflammatory cell infiltrate and lymphoid follicle formation (arrow head). There is also intramucosal fibrosis (arrows) with moderate glandular atrophy, H\&E stain, $\times 100$.

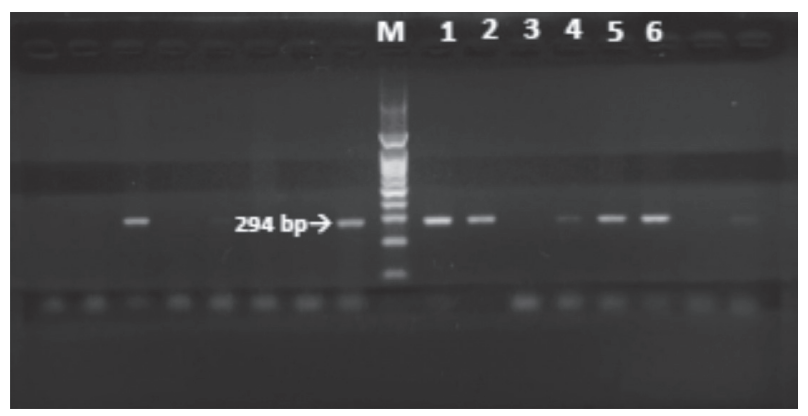

Figure 7: PCR amplification of UreC (glmM) for H. pylori detection: M: 100 bp ladder; lanes 1, 2, and 4-6: positive (at $294 \mathrm{bp}$ ); lane 3: negative. one of them was cagA positive. Out of the $60 \mathrm{H}$. pylori strains tested, $39(66 \%)$ had at least one virulence gene and 21 (34\%) did not show any virulence genes (Table 3 ).

The age of the patients positive for $H$. pylori (60 patients) ranged between 25 and 65 years ( \pm years). It was noticed that $H$. pylori infection increases significantly with age in most of cases, 45/60 (75\%), aged $>45$ years with $P$ value $<0.001$. Genotypes $s 1 m 1$ and $s 2 m 2$ showed statistically significant association with patients aged $>45$ years $(P$ value $<0.001)$, while the association with $s 1 m 2$ was insignificant $(P>0.05)$.

\section{Discussion}

H. pylori is recognized as the most prevalent infectious disease in human being. It causes persistent gastritis that is interrelated to PUD and gastric adenocarcinoma [1]. In all guidelines, $H$. pylori eradication is accepted as the primary priority strategy for preventing gastric cancer [17].

Dyspeptic patients are more likely to have $H$. pylori infection than asymptomatic individuals. The burden of H. pylori infection in our patients with dyspepsia was high; about two-thirds of patients tested positive for RUT. Our findings were close to those of an Egyptian study in Mansoura [18]. The prevalence of $H$. pylori infection in different countries is variable. For instance, it is more than $80 \%$ in many areas such as Japan, South America, Turkey, and Pakistan, while in England it is lower (20\%) [19].

In this study, antral gastritis was the predominant endoscopic finding, representing 36.6\%. Moreover, antral gastritis, diffuse erosive gastroduodenitis, duodenal ulcer, gastric ulcer, and combined duodenal and gastric ulcer showed statistically significant association with RUT $(P<0.001,<0.001,0.03,0.017$, and 0.04 , respectively). Our findings agreed with many studies which reported that most of $H$. pylori patients developed acute gastritis that resolved spontaneously [20]. We noticed that $38.6 \%(58 / 150)$ of our patients were suffering from PUD with $51.7 \%$ (30/58) of them having $H$. pylori. This agrees with a Kenyan study, which reported that $30 \%$ had PUD with $H$. pylori infection [21].

H. pylori cagA is a highly immunogenic protein encoded by $\operatorname{cag} A$ gene. It is associated with cell injury and more severe clinical outcomes, including duodenal ulcer and gastric adenocarcinoma [22]. vacA disrupts epithelial cell tight junctions, alters the host inflammatory response, and suppresses T cell activation [16].

The relation of the $v a c A$ and $c a g A$ genotypes with clinical outcomes represented by endoscopic findings was examined. About two-thirds (66\%) of $H$. pylori positive specimens had two or at least one of the virulence genes examined in our study. vacA and $\operatorname{cag} A$ genotypes were detected in $61.6 \%$ and $53 \%$, respectively, of the $60 \mathrm{H}$. pylori strains. Similarly, a previous study on Cuban patients detected vacA gene in $61.6 \%$ of the studied $H$. pylori strains, considering it the main virulent gene in most of the strains [23]. Another study in Algeria identified the cagA gene in 58\% patients [24], and the percentages were as follows in other countries: in Pakistan, $24.2 \%$ [25], and, in Japan, 90\%, which is correlated with the increased prevalence of gastric cancer in that country [15]. 
TABle 2: Endoscopic findings in relation to RUT and PCR.

\begin{tabular}{|c|c|c|c|c|c|c|}
\hline Findings & $\mathrm{RUT}^{* *}(100)$ & $P$ value & OR $(95 \% \mathrm{CI})$ & $\mathrm{PCR}^{* * *}(60)$ & $P$ value & OR $(95 \% \mathrm{CI})$ \\
\hline Antral gastritis (55) & $55(55 \%)$ & $<0.001^{*}$ & & $20(33.3 \%)$ & 0.489 & $0.8(0.4-1.6)$ \\
\hline Gerd (34) & $36(36 \%)$ & 0.465 & $1.3(0.6-2.7)$ & $15(25 \%)$ & 0.057 & $0.5(0.2-1.0)$ \\
\hline Pangastritis (40) & $30(30 \%)$ & 0.192 & $1.7(0.8-3.9)$ & $5(8.3 \%)$ & $<0.001^{*}$ & $0.1(0.1-0.4)$ \\
\hline Diffuse gastric mucosal nodularity (40) & $20(20 \%)$ & 0.172 & $0.6(0.3-1.3)$ & $10(16.6 \%)$ & 0.115 & $0.5(0.2-1.2)$ \\
\hline Diffuse erosive gastroduodenitis (34) & $15(15 \%)$ & $<0.001^{*}$ & $0.3(0.1-0.6)$ & $8(13.3 \%)$ & $<0.001^{*}$ & $0.1(0.1-0.3)$ \\
\hline Duodenal ulcer (30) & $25(25 \%)$ & $0.030^{*}$ & $3(1.1-8.4)$ & $17(28.3 \%)$ & 0.084 & $0.5(0.3-1.1)$ \\
\hline Gastric ulcer (20) & $18(18 \%)$ & $0.017^{*}$ & $5.3(1.2-23.7)$ & $8(13.3 \%)$ & $<0.001^{*}$ & $0.1(0.1-0.3)$ \\
\hline Combined duodenal and gastric ulcers (8) & $8(8 \%)$ & $0.040^{*}$ & & $5(8.3 \%)$ & $<0.001^{*}$ & $0.1(0.0-0.2)$ \\
\hline Hiatus hernia (3) & $0(0 \%)$ & $0.014^{*}$ & & $0(0 \%)$ & $<0.001^{*}$ & \\
\hline Gastric cancer (3) & $2(2 \%)$ & 1.000 & $1(0.1-11.3)$ & $0(0 \%)$ & $<0.001^{*}$ & \\
\hline Duodenal diverticulum (2) & $0(0 \%)$ & & & $0(0 \%)$ & $<0.001^{*}$ & \\
\hline Gastric polyp (1) & $0(0 \%)$ & 0.156 & & $0(0 \%)$ & $<0.001^{*}$ & \\
\hline Barrette esophagus (1) & $0(0 \%)$ & 0.156 & & $0(0 \%)$ & $<0.001^{*}$ & \\
\hline Normal mucosa (4) & $0(0 \%)$ & 0.156 & & $0(0 \%)$ & $<0.001^{*}$ & \\
\hline
\end{tabular}

${ }^{*} P<0.001$ : highly statistically significant; ${ }^{* *}$ RUT: rapid urease test; ${ }^{* * *}$ PCR: polymerase chain reaction.

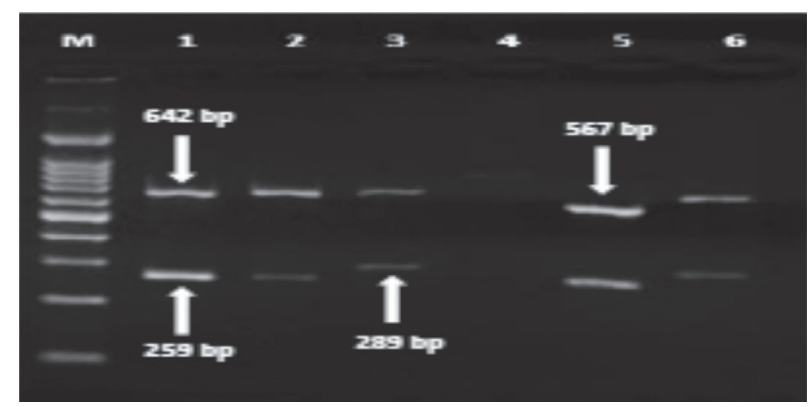

Figure 8: PCR amplification of vacA alleles and cagA: M: 100 bp ladder; lanes 1-3, 5, and 6: vacA+/cagA-; lane 4: vacA-/cagA-; lane 1: s1 $m 2$ genotype; lane 2: $s 1 \mathrm{~m} 2$ genotype; lane 3: $s 2 m 2$ genotype; lane 5: $s 1 m 1$ genotype; lane 6: $s 2 m 2$ genotype.

TABle 3: Association between virulence genes and endoscopic findings in $H$. pylori strains (no. $=60$ ).

\begin{tabular}{|c|c|c|c|c|c|c|c|c|c|}
\hline \multirow[b]{2}{*}{$\begin{array}{l}\text { Virulence } \\
\text { genes }\end{array}$} & \multirow[b]{2}{*}{$\begin{array}{c}\text { vacA genotypes } \\
\text { (No.) }\end{array}$} & \multicolumn{8}{|c|}{ Endoscopic findings $(n=60)$} \\
\hline & & $\begin{array}{l}\text { PUD* (30) } \\
\text { No. }(\%)\end{array}$ & $P$ value & $\begin{array}{c}\text { Gastritis (25) } \\
\text { No. (\%) }\end{array}$ & $P$ value & $\begin{array}{c}\text { GERD }^{* *}(15) \\
\text { No. }(\%)\end{array}$ & $P$ value & $\begin{array}{c}\text { Others (18) } \\
\text { No. (\%) }\end{array}$ & $P$ value \\
\hline \multirow{3}{*}{$\operatorname{vac} A+/ \operatorname{cag} A+$} & $s 1 m 1(26)$ & $10(33.3 \%)$ & & $12(20 \%)$ & & $8(13.3 \%)$ & & $6(10 \%)$ & \\
\hline & $s 1 m 2(5)$ & $5(16.6 \%)$ & $<0.001^{*}$ & $4(6.6 \%)$ & $<0.001^{*}$ & $2(3.3 \%)$ & $<0.001^{*}$ & $0(0.0 \%)$ & $<0.001^{*}$ \\
\hline & $s 2 m 2(1)$ & $1(3.3 \%)$ & & $0(0.0 \%)$ & & $1(1.6 \%)$ & & $0(0.0 \%)$ & \\
\hline \multirow{3}{*}{$\begin{array}{l}\operatorname{vac} A+1 \\
\operatorname{cag} A-\end{array}$} & $s 1 m 1(1)$ & $0(0.0 \%)$ & & $1(3.3 \%)$ & & $0(0.0 \%)$ & & $0(0.0 \%)$ & \\
\hline & $s 1 m 2(2)$ & $1(3.3 \%)$ & 0.392 & $1(3.3 \%)$ & 0.392 & $0(0.0 \%)$ & & $0(0.0 \%)$ & \\
\hline & $s 2 m 2(2)$ & $0(0.0 \%)$ & & $2(6.6 \%)$ & & $0(0.0 \%)$ & & $0(0.0 \%)$ & \\
\hline $\begin{array}{l}\text { vacA-l } \\
\text { cagA- }\end{array}$ & & $13(23.3 \%)$ & & $5(11.6 \%)$ & & $4(1.6 \%)$ & & $12(16.6 \%)$ & \\
\hline
\end{tabular}

*PUD: Peptic Ulcer Disease. ${ }^{* *}$ GERD: Gastroesophageal Reflux Disease.

Because of the high degree of geographic variability of $H$. pylori, certain $H$. pylori genotypes are possibly associated with severe clinical outcomes in some countries, while presenting as less harmful or even harmless variants in other regions. The observed discrepancies in different studies regarding $H$. pylori virulence genes may be attributed to difference in facilities or the limitations of PCR methods.

Regarding cagA and $V a c A$ genotypes, we found that $v a c A+\operatorname{cag} A+/ s 1 m 1$ was the most predominant $(26 / 60$, $43.3 \%)$. Similarly, $s 1 m 1$ genotype is the most prevalent genotype in Asian population [26]. In our series, we noticed that H. pylori infected patients with PUD, gastritis, and GERD (50\%, 41.6\%, and 25\%, respectively) had a statistically significant association with cagA genotype $(P<0.001)$. This agrees with a Saudi study which confirmed the association between vacA genotype and severe gastric endoscopic findings [27].

However, $\operatorname{cag} A+$ was not found in our study as a single genotype. It was rather linked to vacA $s 1 m 1$ in $(26 / 60)$, vacA $s 1 m 2(5 / 60)$, or $s 2 m 2(1 / 60)$. 
In this study, a lower percentage of vacA $s 2 \mathrm{~m} 2$ genotype was noticed, which is considered as a less virulent form as compared with the acutely damaging $v a c A s 1 \mathrm{~m} 1$ as stated by Falsafi and his colleagues [28]. In our studied population, $v a c A+/ \operatorname{cag} A$ - genotype $s 1 m 1$ was the least prevalent, and this is consistent with an Iranian study that was carried out in 2015 [28].

\section{Conclusion}

Helicobacter pylori infection is prevalent among dyspeptic patients. The main genotype combinations in our studied population were $v a c A+/ \operatorname{cag} A+$ of $s 1 m 1$ genotype and they were frequently associated with gastritis and GERD, while vacA-/cagA- patients presented mainly with gastritis. The less virulent $(s 2 m 2)$ genotypes were found in $v a c A+/ c a g A-$ and $v a c A+/ \operatorname{cag} A+$ patients. Eventually, the advanced molecular methods are recently used as dependable tools for characterization of $H$. pylori virulent strains because of their increasing sensitivity and specificity.

\subsection{Main Points}

(i) Helicobacter pylori infection is prevalent among dyspeptic patients reflecting the increased risk of gastric disorders including gastric carcinoma.

(ii) Knowledge of $H$. pylori virulence genes can be of clinical significance through improving the clinical prediction of disease risk and identifying those in need to more surveillance and eradication of the infection to prevent serious consequences.

(iii) Advanced molecular methods can be used as dependable tools for characterization of $H$. pylori virulent strains because of their increasing sensitivity and specificity.

\section{Data Availability}

The data supporting the findings of this study are available within the article.

\section{Ethical Approval}

The study was approved by the Research Ethics Committee, Faculty of Medicine, Suez Canal University.

\section{Consent}

A verbal consent was obtained from the patients involved in the study.

\section{Conflicts of Interest}

The authors declare that they have no conflicts of interest.

\section{Authors' Contributions}

All authors contributed to the study conception and design, in addition to material preparation, data collection, and analysis. All authors commented on previous versions of the manuscript; also, they read and approved the final manuscript.

\section{References}

[1] M. A. Chiurillo, Y. Moran, M. Cañas et al., "Genotyping of Helicobacter pylori virulence-associated genes shows high diversity of strains infecting patients in western Venezuela," International Journal of Infectious Diseases, vol. 17, no. 9, pp. e750-e756, 2013.

[2] M. K. Tummuru, T. L. Cover, and M. J. Blaser, "Mutation of the cytotoxin-associated cagA gene does not affect the vacuolating cytotoxin activity of Helicobacter pylori," Infection and Immunity, vol. 62, no. 6, pp. 2609-2613, 1994.

[3] J. M. Whitmire and D. S. Merrell, "Helicobacter pylori genetic polymorphisms in gastric disease development," Advances in Experimental Medicine and Biology, vol. 1149, pp. 173-194, 2019.

[4] B. Kalali, R. Mejías-Luque, A. Javaheri, and M. Gerhard, " $H$. pylori virulence factors: influence on immune system and pathology," Mediators Inflamm, vol. 2014, Article ID 426309, 9 pages, 2014.

[5] J. Mahdavi, B. Sondén, M. Hurtig et al., "Helicobacter pylori sabA adhesin in persistent infection and chronic inflammation," Science, vol. 297, no. 5581, pp. 573-578, 2002.

[6] S. Backert and M. J. Blaser, "The role of cagA in the gastric biology of Helicobacter pylori," Cancer Research, vol. 76, no. 14, pp. 4028-4031, 2016.

[7] K. R. Jones, J. M. Whitmire, and D. S. Merrell, “A tale of two toxins: Helicobacter pylori cagA and vacA modulate host pathways that impact disease," Frontiers in Microbiology, vol. 1, p. 115, 2010.

[8] N. J. Foegeding, R. R. Caston, M. S. McClain, M. D. Ohi, and T. L. Cover, "An overview of Helicobacter pylori vacA toxin biology," Toxins, vol. 8, no. 6, 2016.

[9] M. S. McClain, A. C. Beckett, and T. L. Cover, "Helicobacter pylori vacuolating toxin and gastric cancer," Toxins, vol. 9, no. 10, 2017.

[10] D. R. Bridge and D. S. Merrell, "Polymorphism in the Helicobacter pylori cagA and vacA toxins and disease," Gut Microbes, vol. 4, no. 2, pp. 101-117, 2013.

[11] J. C. Atherton, P. Cao, R. M. Peek, M. K. R. Tummuru, M. J. Blaser, and T. L. Cover, "Mosaicism in vacuolating cytotoxin alleles of Helicobacter pylori," Journal of Biological Chemistry, vol. 270, no. 30, pp. 17771-17777, 1995.

[12] M. F. Dixon, R. M. Genta, J. H. Yardley, and P. Correa, "Classification and grading of gastritis," The American Journal of Surgical Pathology, vol. 20, no. 10, pp. 1161-1181, 1996.

[13] J.-J. Lu, C.-L. Perng, R.-Y. Shyu et al., "Comparison of five PCR methods for detection of Helicobacter pylori DNA in gastric tissues," Journal of Clinical Microbiology, vol. 37, no. 3, pp. 772-774, 1999.

[14] H. M. Malaty, D. Y. Graham, D. G. Klein, E. E. Adam, D. J. Evans, and D. J. Evans, "Transmission of Helicobacter pylori infection studies in families of healthy individuals," Scandinavian Journal of Gastroenterology, vol. 26, no. 9, pp. 927-932, 1991.

[15] Y. Ito, T. Azuma, S. Ito et al., "Analysis and typing of the vacA gene from cagA-positive strains of Helicobacter pylori isolated in Japan," Journal of Clinical Microbiology, vol. 35, no. 7, pp. 1710-1714, 1997.

[16] D. Y. Graham and Y. Yamaoka, "Disease-specific Helicobacter pylori virulence factors: the unfulfilled promise," Helicobacter, vol. 5, no. S1, pp. S3-S9, 2000. 
[17] S. Chattopadhyay, R. Patra, T. Ramamurthy et al., "Multiplex PCR assay for rapid detection and genotyping of Helicobacter pylori directly from biopsy specimens," Journal of Clinical Microbiology, vol. 42, no. 6, pp. 2821-2824, 2004.

[18] H. B. El-Serag, J. Y. Kao, F. Kanwal et al., "Houston consensus conference on testing for Helicobacter pylori infection in the United States," Clinical Gastroenterology and Hepatology, vol. 16, no. 7, pp. 992-1002.e6, 2018.

[19] B. Suvak, A. Dulger, O. Suvak, E. Aytemiz, and O. Kemik, "The prevalence of Helicobacter pylori among dyspeptic patients in an earthquake-stricken area," Clinics, vol. 70, no. 1, pp. 69-72, 2015.

[20] A. H. Latif, S. K. Shami, R. Batchoun, N. Murad, and O. Sartawi, "Helicobacter pylori: a jordanian study," Postgraduate Medical Journal, vol. 67, no. 793, pp. 994-998, 1991.

[21] A. N. Kimang'a, G. Revathi, S. Kariuki, S. Sayed, and S. Devani, "Helicobacter pylori: prevalence and antibiotic susceptibility among Kenyans," South African Medical Journal=Suid-Afrikaanse Tydskrif Vir Geneeskunde, vol. 100, no. 1, pp. 53-57, 2010.

[22] D. Y. Graham, L. C. Alpert, J. L. Smith, and H. H. Yoshimura, "Iatrogenic Campylobacter pylori infection is a cause of epidemic achlorhydria," The American Journal of Gastroenterology, vol. 83, no. 9, pp. 974-980, 1988.

[23] O. Feliciano, O. Gutierrez, L. Valdés et al., "Prevalence of Helicobacter pylori vacA, cagA, and iceA genotypes in cuban patients with upper gastrointestinal diseases," BioMed Research International, vol. 2015, Article ID 753710, 6 pages, 2015.

[24] M. Bachir, R. Allem, A. Tifrit et al., "Primary antibiotic resistance and its relationship with cagA and vacA genes in Helicobacter pylori isolates from algerian patients," Brazilian Journal of Microbiology, vol. 49, no. 3, pp. 544-551, 2018.

[25] T. Ahmad, K. Sohail, M. Rizwan, M. Mukhtar, R. Bilal, and A. Khanum, "Prevalence of helicobacter pyloripathogenicityassociated cagA and vacA genotypes among Pakistani dyspeptic patients," FEMS Immunology \& Medical Microbiology, vol. 55, no. 1, pp. 34-38, 2009.

[26] A. A. Memon, N. R. Hussein, V. Y. Miendje Deyi, A. Burette, and J. C. Atherton, "Vacuolating cytotoxin genotypes are strong markers of gastric cancer and duodenal ulcer-associated Helicobacter pylori strains: a matched case-control study," Journal of Clinical Microbiology, vol. 52, no. 8, pp. 2984-2989, 2014.

[27] M. A. M. Marie, "Relationship between Helicobacter pylori virulence genes and clinical outcomes in Saudi patients," Journal of Korean Medical Science, vol. 27, no. 2, pp. 190-193, 2012.

[28] T. Falsafi, A. Khani, F. Mahjoub, E. Asgarani, and N. Sotoudeh, "Analysis of $\operatorname{vacA} / \operatorname{cagA}$ genotypes/status in Helicobacter pylori isolates from Iranian children and their association with clinical outcome," Turkish Journal of Medical Sciences, vol. 45, no. 1, pp. 170-177, 2015. 